\title{
PENGEMBANGAN BAHAN AJAR BARISAN DAN DERET MATEMATIKA BERBASIS MULTIMEDIA INTERAKTIF
}

\author{
Endro Setiawan ${ }^{1}$, Swaditya Rizki ${ }^{2}$ \\ ${ }^{1,2}$ Pendidikan Matematika, Universitas Muhammadiyah Metro \\ E-mail: $\quad$ endrosetiawan20@gmail.com ${ }^{1)}$ \\ swadityarizki@ummetro.ac.id ${ }^{2)}$
}

Received 30 November 2018; Received in revised form 28 December 2018; Accepted 30 December 2018

\begin{abstract}
The objective of this development research was to produce the learning materials of sequence and series based on interactive multimedia that were valid and practical to use for the student. This research type was Research and Development $(R \& D)$. The model used in this research was Plomp model consisting of three phases, namely preliminary research, prototype, and assessment. The instrument used questionnaire consisting of two types of questionnaires, the first expert validation questionnaire conducted by two material experts and two learning material design experts. The second, the student response questionnaire was conducted by 10 students of Vocational high School of Muhammadiyah 1 Metro. Based on the validations process were obtained the result that the average percentage of material experts was $82.01 \%$ in the very feasible category. The results of the assessment of students' response questionnaires was obtained the average percentage of $87.55 \%$ with a very practical category. Based on the exposure to the results of the validity and practicality test, it can be concluded that the learning materials of sequence and series based on interactive multimedia are valid and practical for learning.
\end{abstract}

Keywords: interactive multimedia; mathematic; $R \& D$; sequence and series.

\section{PENDAHULUAN}

Matematika merupakan salah satu bidang studi yang menduduki peranan penting dalam pendidikan, sebagai bukti adalah pelajaran matematika diberikan kepada semua jenjang pendidikan mulai dari Sekolah Dasar sampai Perguruan Tinggi. Mengingat pentingnya matematika, maka dalam pengajarannya bukan hanya untuk mengetahui dan memahami apa yang terkandung dalam matematika itu sendiri, tetapi lebih menekankan pada pola berpikir peserta didik agar dapat memecahkan masalah secara kritis, logis, kreatif, cermat, dan teliti.

Menurut Sutarti dan Irawan (2017), penelitian dan pengembangan pendidikan adalah proses yang digunakan untuk mengembangkan produk berdasarkan temuan, kemudian divalidasi dan direvisi sampai menjadi produk akhir yang siap digunakan.
Sedangkan menurut Wisnu, Made, dan Aditra (2017) menyatakan bahwa penelitian dan pengembangan atau reaserch and development ( $\mathrm{R} \& \mathrm{D})$ Metode pengembangan ini merupakan cara yang digunakan untuk menemukan, mengembangkan dan menguji suatu produk berdasarkan prosedur yang sistematis sehingga produk yang dihasilkan memiliki nilai ilmiah yang tinggi dan dapat dipercaya. Selain itu, Rahmawati \& Rizki (2017) juga menyatakan bahwa pengembangan bahan ajar perlu dilakukan untuk menyesuaikan kebutuhan belajar peserta didik.

Salah satu bentuk pengembangan bahan ajar yaitu berbasis teknologi informasi. Pengembangan bahan ajar berbasis multimedia interaktif ini menggunakan Microsoft Powerpoint dan Ispring. Menurut Suprapti (2016) Microsoft Powerpoint 
merupakan program untuk membuat presentasi dengan fasilitas yang ada dapat digunakan untuk membuat media pembelajaran, program yang dihasilkan cukup menarik jika digabungkan dengan menggunakan software Ispring Suite 8 yang dapat merubahnya menjadi media animasi dalam bentuk flash. Ispring merupakan salah satu tool yang mengubah file presentasi menjadi bentuk flash dan bentuk SCORM/AICC, yaitu bentuk yang biasa digunakan dalam pembelajaran $e$ learning LMS (Learning Management System). Kemudian Wagino dan Zaenuddin (2015) menyatakan bahwa "perangkat lunak Ispring tersedia dalam versi free (gratis) dan pro (berbayar).

Pengembangan bahan ajar merupakan salah satu solusi untuk menarik minat siswa dalam mempelajari matematika. Banyak jenis bahan ajar yang sudah dikembangkan oleh pendidik maupun peneliti, salah satunya yaitu bahan ajar yang berbasis teknologi informasi. Sepertinya yang dikembangkan oleh Mardiana dan Qohar (2017); Yusri dan Husaini (2017); Khuzaini dan Santosa (2016); Nugraha dan Muhtadi (2015); Bardi dan Jailani (2015); Riyadi dan Pardjono (2014); Fahmi dan Marsigit (2014); Istiqlal dan Wutsqa (2013); Novaliendry (2013) yaitu tentang multimedia dalam pembelajaran matematika.

Dari beberapa penelitian tersebut, materi yang dikembangkan berbeda-beda dengan bentuk multimedia. Namun, materi barisan dan deret belum ada yang mengembangkan bahan ajar dalam bentuk multimedia. Bahan ajar yang ada hanya berbentuk modul atau sejenisnya.

Berdasarkan hasil pra-survei
dilakukan, Muhammadiyah 1 Metro memiliki fasilitas-fasilitas yang memadai dan menunjang kegiatan pembelajaran dan dikembangkannya bahan ajar matematika berbasis multimedia dan antara lain seperti fasilitas LCD (Liquid Crystal Display) yang terdapat pada tiap-tiap kelas dan ruang laboratorium komputer. Disamping itu, berdasarkan wawancara dengan salah satu pendidik matematika, didapatkan beberapa permasalahan diantaranya yaitu terbatasnya bahan ajar pembelajaran yang digunakan dalam proses pembelajaran dan belum sesuai kebutuhan peserta didik. Selain itu bahan ajar yang digunakan dalam proses pembelajaran yaitu bahan ajar menggunakan powerpoint, akan tetapi bahan ajar yang menggabungkan unsur teks, suara, gambar, video, dan animasi serta kuis interaktif belum pernah digunakan dalam proses pembelajarannya.

Oleh karena itu, untuk memenuhi kebutuhan peserta didik tersebut, diperlukan bahan ajar dengan memanfaatkan teknologi informasi sehingga diharapkan dapat menumbuhkan minat peserta didik dalam memahami konsep materi barisan dan deret. Bahan ajar yang dikembangkan adalah bahan ajar berbentuk multimedia interaktif yaitu gabungan beberapa media dalam menyampaikan informasi yang berupa teks, grafik atau animasi grafis, movie, video, dan audio. Pengguna bisa berinteraksi dengan multimedia tersebut seperti memilih menu yang akan dibuka serta dapat mengerjakan soal tes melalui media tersebut. Informasi yang ditampilkan tidak hanya dapat dilihat sebagai hasil cetakan, melainkan juga dapat didengar, membentuk simulasi dan animasi yang dapat membangkitkan minat dan memiliki nilai seni grafis yang tinggi dalam penyajiannya.

Penggabungan Microsoft

Powerpoint dan Ispring dapat menjadikan file presentasi atau bahan 
ajar menjadi media animasi yang lebih menarik dan interaktif, dapat membuat berbagai kuis dengan berbagai jenis pertanyaan dan dapat menyisipkan berbagai bentuk media seperti teks, gambar, animasi, audio, video serta dapat merekam dan sinkronasi video presenter, menambahkan flash dan video youtube. Oleh Karena itu, tujuan dari penelitian pengembangan ini adalah untuk menghasilkan bahan ajar matematika berbasis multimedia interaktif yang valid dan praktis sesuai kebutuhan peserta didik.

\section{METODE PENELITIAN}

$\begin{array}{llr}\text { Prosedur } & \begin{array}{c}\text { pengembangan } \\ \text { berdasarkan }\end{array} & \begin{array}{r}\text { yang } \\ \text { model }\end{array} \\ \text { dilakukan } & \text { Nieveen }\end{array}$ (2013) yang terdiri dari 3 fase yaitu:

\section{a. Preliminary research}

Pada tahap ini kegiatan yang dilakukan yaitu menemukan analisis permasalahan yang ada, guna untuk mengembangkan bahan ajar berbasis multimedia. Selain itu dilakukan analisis kurikulum, menganalisis peserta didik dan menganalisis materi yang menggunakan bahan ajar.

\section{b. Prototyping}

Tahap ini digunakan untuk mendesain bahan ajar berbasis multimedia, menyusun instrumen penelitian meliputi validitas bahan ajar berbasis multimedia, instrumen ketertarikan peserta didik berupa angket dari peserta didik. Setelah terkumpul bahan ajar dan instrumen tersebut maka dihasilkan berupa produk sementara. Produk sementara akan dilanjutkan ke tahap validasi oleh para ahli, setelah para ahli menilai, kemudian dilanjutkan ketahap berikutnya yaitu pembuatan bahan ajar berbasis multimedia.

\section{c. Assesment}

Tahapan akhir ini dilakukan validitas bahan ajar dan uji coba terbatas. Validitas bahan ajar dilakukan guna menentukan kelayakan dari sebuah bahan ajar berbasis multimedia yang dikembangkan. Bahan ajar berbasis multimedia divalidasi oleh 3 validator yang terdiri dari ahli desain dan materi. Hasil validasi dilakukan analisis dan revisi terhadap produk sementara.

Selanjutnya setelah produk direvisi, kemudian dilakukan uji coba terbatas, di mana uji coba terbatas ini dilaksanakan di SMK Muhammadiyah 1 Metro pada kelas $\mathrm{X}$ berjumlah 10 orang siswa untuk mengetahui kepraktisan dari sebuah bahan ajar berbasis multimedia tersebut. Selanjutnya direvisi kembali menjadi bahan ajar berbasis multimedia yang benar-benar layak digunakan.

Instrumen pengumpulan data yang digunakan untuk memperoleh sejumlah data yakni berupa angket. Angket yang digunakan adalah jenis angket yang berisi rating scale. Adapun angket yang digunakan adalah angket penilaian ahli materi dan ahli desain, serta respon peserta didik.

Analisis data yang digunakan yaitu data kuantitatif dan kualitatif dari angket yang divalidasi oleh ahli dan respon peserta didik. Hasil validasi ahli digunakan untuk mengetahui kevalidan atau kelayakan bahan ajar berbasis multimedia. Sedangkan hasil respon peserta didik digunakan untuk mengetahui kepraktisan bahan ajar.

\section{HASIL PENELITIAN DAN PEMBAHASAN}

Bahan ajar pembelajaran
matematika berbasis multimedia interaktif pada materi barisan dan deret kelas $\mathrm{X}$ SMK ini dikembangkan menggunakan software Microsoft PowerPoint dan Ispring. Berikut ini produk hasil pengembangan bahan ajar barisan dan deret berbasis multimedia: 


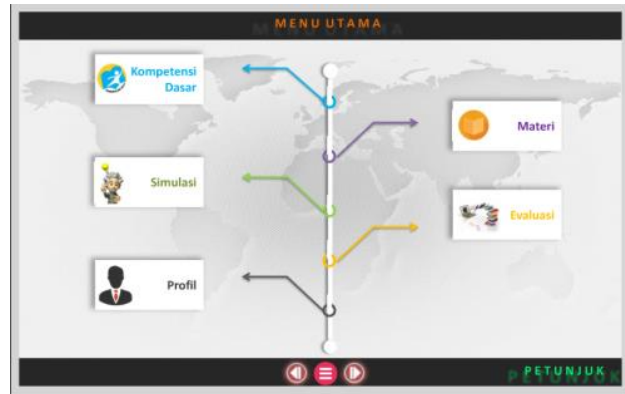

Gambar 1. Tampilan Halaman Menu Utama

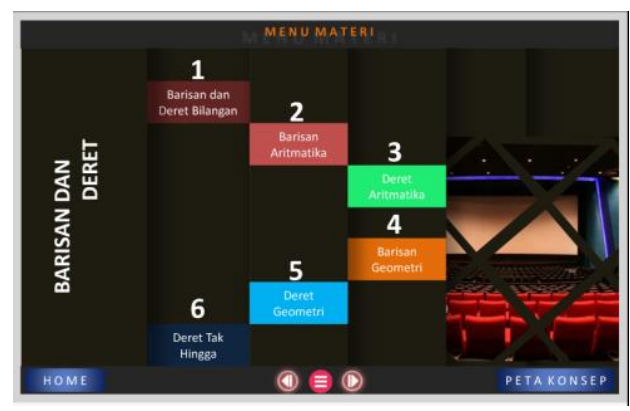

Gambar 2. Tampilan Menu Materi.

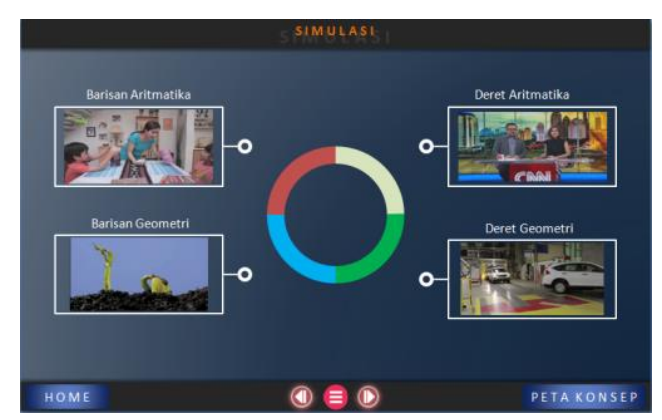

Gambar 3. Tampilan Halaman Simulasi Video

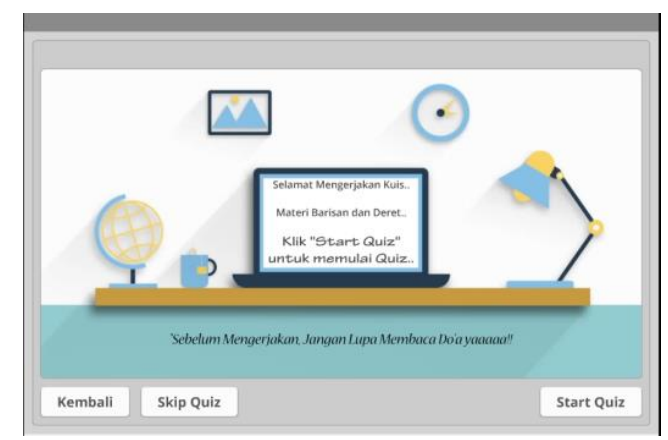

Gambar 4. Tampilan Halaman Evaluasi atau Kuis.
Gambar 1 terdiri dari menu utama berisi menu petunjuk, kompetensi dasar, materi, simulasi, evaluasi, dan profil. Gambar 2 berisi materi berisi beberapa subbab dari materi barisan dan deret yang didalamnya dilengkapi dengan materi, contoh soal, simulasi, dan latihan soal. Gambar 3 berisi simulasi, berisi tentang latihan soal berbentuk video dan dilengkapi dengan suara. Pengguna dapat menjawab soal dengan mengklik salah satu tampilan awal video tersebut dan memperhatikan video dan menyimak pertanyaan yang disampaikan di dalam video. Gambar 4 berisi evaluasi berisi latihan-latihan soal dari keseluruhan materi dengan dilengkapi login nama dan kelas. Evaluasi akan menampilkan skor diperoleh peserta didik setelah menyelesaikan semua soal yang ada di dalamnya. Peserta didik dapat memulai dengan menekan tombol start quiz untuk masuk ke halaman identitas dan memulai kuis.

Berdasarkan pengujian produk terhadap uji kevalidan dan kepraktisan bahan ajar diperoleh data hasil penelitian sebagai berikut:

1. Hasil Validasi para Ahli

Secara keseluruhan hasil validasi oleh para ahli dijabarkan ke dalam Tabel 1.

Tabel 1. Rata-Rata Persentase Tingkat Kelayakan Bahan Ajar

\begin{tabular}{|c|c|c|}
\hline Validator & $\begin{array}{l}\text { Rata-rata } \\
\text { Persentase }\end{array}$ & Kategori \\
\hline Ahli Materi & $87,36 \%$ & $\begin{array}{l}\text { Sangat } \\
\text { layak }\end{array}$ \\
\hline Ahli Desain & $76,65 \%$ & Layak \\
\hline Rata-rata & $82,01 \%$ & $\begin{array}{l}\text { Sangat } \\
\text { layak }\end{array}$ \\
\hline
\end{tabular}

Berdasarkan data hasil perhitungan pada Tabel 1 diperoleh persentase rata-rata yang diberikan 
validator adalah $82,01 \%$ yang masuk kedalam kategori sangat layak, maka dapat disimpulkan bahwa bahan ajar matematika berbasis multimedia dapat diujicobakan di lapangan.

\section{Hasil Uji Coba Kepraktisan}

Bahan ajar matematika berbasis multimedia ini diujicobakan terbatas pada kelompok kecil. Uji coba kelompok kecil dilakukan kepada peserta didik SMK Muhammadiyah 1 Metro kelas XI yang berjumlah 10 peserta didik dengan menggunkan angket respon peserta didik. Secara keseluruhan hasil uji coba kelompok kecil disajikan pada Tabel 2:

Tabel 2. Data Analisis Angket Respon Peserta Didik

\begin{tabular}{lccc}
\hline \multicolumn{1}{c}{ Peserta Didik } & Skor & $\begin{array}{c}\text { Rata-rata } \\
\text { Persentase }\end{array}$ & Kategori \\
\hline Della Afriyanti & 62 & $88,5 \%$ & Sangat setuju \\
Dwi Nurmalasari & 62 & $88,5 \%$ & Sangat setuju \\
Ronal Ivan Mardova & 70 & $100 \%$ & Sangat setuju \\
Suci Desma & 65 & $92,8 \%$ & Sangat setuju \\
Dita Indah Sari & 56 & $80 \%$ & Setuju \\
Desta Indah Sari & 59 & $84,3 \%$ & Sangat setuju \\
Tamara Sukma, SPM & 61 & $87,1 \%$ & Sangat setuju \\
Risna Nur Otaviani & 60 & $85,7 \%$ & Sangat setuju \\
Trias Khavivah & 59 & $84,3 \%$ & Sangat setuju \\
Denna Delfia Devi & 59 & $84,3 \%$ & Sangat setuju \\
Jumlah & 613 & $87,55 \%$ & Sangat praktis \\
\hline
\end{tabular}

Berdasarkan analisis data masing-masing angket respon peserta didik pada Tabel 2, diperoleh hasil kepraktisan bahan ajar dengan rata-rata persentase skor sebesar 87,55\% dan termasuk ke dalam kategori sangat praktis. Setelah dilakukan uji kevalidan dan uji kepraktisan kepada peserta didik, masih terdapat beberapa perbaikan yang dilakukan terhadap bahan ajar matematika berbasis multimedia berdasarkan komentar dan saran yang diberikan oleh para ahli dan peserta didik.

Produk awal digunakan untuk uji kevalidan bahan ajar sebelum digunakan untuk uji coba lapangan, dilakukan oleh ahli materi dan ahli desain bahan ajar dan diperoleh hasil rata-rata persentase sebesar $82,01 \%$ yang masuk ke dalam kategori sangat layak. Selain memberikan penilaian para ahli juga memberikan komentar dan saran untuk dilakukan perbaikan terhadap bahan ajar sebelum dilakukan uji coba terbatas. Adapun perbaikan yang dilakukan yaitu meliputi penambahan contoh dan latihan soal, memperbaiki tata letak kesimpulan, pewarnaan obyek, desain peta konsep, dan menganti jenis video. Setelah dilakukan perbaikan, kemudian dilakukan uji coba terbatas terhadap peserta didik dengan angket respon peserta didik guna untuk mengetahui kepraktisan bahan ajar yang telah dikembangkan dan diperoleh komentar dan saran yang diberikan oleh peserta didik. Berdasarkan uji coba terbatas, diperoleh data kepraktisan dengan ratarata persentase sebesar $87,55 \%$ yang masuk ke dalam kategori sangat praktis. Berdasarkan rata-rata persentase yang diperoleh, dapat disimpulkan bahwa 
bahan ajar matematika berbasis multimedia dapat digunakan dalam pembelajaran.

Bahan ajar matematika berbasis multimedia ini menjadi bahan ajar yang mampu memecahkan permasalahan dalam proses pembelajaran. Bahan ajar ini sangat mudah dibuka, baik melalui komputer maupun handphone. Selain itu, bahan ajar matematika berbasis multimedia ini menjadi inovasi pembelajaran matematika, karena bahan ajar ini sangat praktis untuk dipelajari sehingga dapat menarik minat peserta didik dalam mempelajari matematika.

Kelebihan bahan ajar ini yaitu memiliki tampilan desain yang menarik, baik dari segi teks, obyek, gambar, warna maupun animasi. Selain itu, bahan ajar ini bersifat interaktif yang dapat dipelajari peserta didik secara mandiri maupun kelompok. Bahan ajar berbasis multimedia ini juga dilengkapi dengan animasi dan video pembelajaran, serta soal-soal evaluasi sehingga sangat menarik. Peserta didik dapat mengerjakan soal evaluasi langsung dari media tersebut dan langsung dapat mengetahui skor yang diperolehnya.

Pembelajaran matematika menggunakan bahan ajar barisan dan deret berbasis multimedia interaktif ini sangat baik dan bermanfaat sesuai kebutuhan peserta didik. Terlebih lagi di era revolusi industri 4.0 ini peserta didik sudah selayaknya memanfaatkan teknologi dalam proses pembelajarannya. Hal ini sejalan dengan penelitian yang dilakukan oleh Mardiana dan Qohar (2017); Yusri dan Husaini (2017); Khuzaini dan Santosa (2016); Nugraha dan Muhtadi (2015); Bardi dan Jailani (2015); Riyadi dan Pardjono (2014); Fahmi dan Marsigit (2014); Istiqlal dan Wutsqa (2013) bahwa multimedia mempunyai dampak yang baik bagi peserta didik dalam memahami materi matematika.

\section{KESIMPULAN DAN SARAN}

Dari hasil penelitian dan pengembangan yang telah dilakukan dapat disimpulkan bahwa bahan ajar barisan dan deret matematika berbasis multimedia interaktif ini sangat layak dan praktis digunakan sesuai kebutuhan peserta didik. Kelebihan bahan ajar berbasis multimedia interaktif ini yaitu memiliki tampilan yang menarik karena disertai gambar, video, dan animasi dan bersifat interaktif sehingga pengguna bisa dengan mudah memahami materi. Selain itu, bahan ajar berba.sis multimedia interaktif ini dapat menarik minat peserta didik dalam belajar, karena bahan ajar ini bisa dibuka dan dipelajari melalui handphone.

Adapun saran dari penelitian dan pengembangan bahan ajar berbasis multimedia interaktif ini yaitu perlu dilakukan ujicoba kelompok besar yang melibatkan banyak sekolah di berbagai wilayah, sehingga dapat diketahui efektifitasnya dari bahan ajar ini. Selain itu, bahan ajar ini dapat dikembangkan lebih lanjut berbasis aplikasi android sehingga peserta didik dapat lebih mudah mencari bahan ajar tersebut.

\section{DAFTAR PUSTAKA}

Bardi \& Jailani. (2015). Pengembangan Multimedia Berbasis Komputer Untuk Pembelajaran Matematika Bagi Siswa SMA. Jurnal Inovasi Teknologi Pendidikan, 2(1), 49-63.

Fahmi, S., \& Marsigit. (2014). Pengembangan Multimedia Macromedia Flash dengan Pendekatan Kontekstual dan Keefektifannya terhadap Sikap 
Siswa pada Matematika. PYTHAGORAS: Jurnal Pendidikan Matematika, 9(1), 90-98.

Istiqlal, M., \& Wutsqa, D.U. (2013). Pengembangan Multimedia Pembelajaran Matematika SMA untuk Meningkatkan Motivasi dan Prestasi Belajar Matematika Materi Logika Matematika. PYTHAGORAS: Jurnal Pendidikan Matematika, 8(1), 44-54.

Khuzaini, N., \& Santosa, R.H. (2016). Pengembangan Multimedia Pembelajaran Trigonometri Menggunakan Adobe Flash CS3 Untuk Siswa SMA. Jurnal Riset Pendidikan Matematika, 3(1), 88-99.

doi:http://dx.doi.org/10.21831/jr pm.v3i1.9681

Mardiana, S. \& Qohar, A. (2017). Pengembangan Media Interaktif Berbasis Penemuan Terbimbing 'Transgeo' Pada Materi Translasi Untuk Siswa Kelas XI. AKSIOMA Jurnal Pendidikan Matematika FKIP Universitas Muhammadiyah Metro, 6(1), 2027.

Novaliendry, D. (2013). Aplikasi Game Geografi Berbasis Multimedia Interaktif (Studi Kasus Siswa Kelas IX SMPN 1 RAO). Jurnal Teknologi Informasi \& Pendidikan, 6(2), 106-118

Nugraha, A.N.C., \& Muhtadi, A. (2015). Pengembangan Multimedia Pembelajaran Matematika Pada Materi Bangun Ruang Sisi Datar Untuk Siswa SMP Kelas VIII. Jurnal
Inovasi Teknologi Pendidikan, 2(1), 16-31.

Plomp, T., \& Nieveen. (2013). An Introduction to Educational Design Research. SLO Netherlands Institute for Curriculum Development.

Rahmawati, A. \& Rizki, S. (2017). Pengembangan Bahan Ajar Matematika Berbasis Nilai-Nilai Islam Pada Materi Aritmatika Sosial. Jurnal Aksioma Pendidikan Matematika FKIP Univ. Muhammadiyah Metro. 6(1), 81-88.

Riyadi, S. \& Pardjono. (2014). Pengembangan Multimedia Pembelajaran Matematika Berbasis Komputer Untuk Kelas VIII SMP. Jurnal Inovasi Teknologi Pendidikan 1(2), 165 177

Suprapti, E. (2016). Pengembangan Perangkat Pembelajaran Matematika Model Kooperatif Tipe STAD dengan Media Powerpoint Ispring pada Materi Jajargenjang, Layang-Layang, dan Trapesium di Kelas VII SMP. Journal of Mathematics Education, Science, And Tecnology, $\quad$ 1(1). FKIPUniversitas Muhammadiyah Surabaya.

Sutarti, T., \& Irawan, E. (2017). Kiat Sukses Meraih Hibah Penelitian Pengembangan. Yogyakarta: CV. Budi Utama

Wagino \& Zaenuddin. (2015). Pembuatan media pembelajaran interaktif dengan perangkat lunak ispring presentar di 
ISSN 2089-8703 (Print) Vol. 7, No. 3 (2018) 465-472

ISSN 2442-5419 (Online)

SMAN 4 banjarmasin. Jurnal Al-ikhlas. Vol.1, No. 1. 20-27.

Wisnu, K.B.P., Made, I.A.W., \& Aditra, G.P. (2017). Pengaruh E-Modul Berbasis Model Pembelajaran Discovery Learning pada Mata Pelajaran "Sistem Komputer" untuk Siswa Kelas X Multimedia SMK Negeri 3 Singaraja. Jurnal Pendidikan Teknologi dan Kejuruan. 14(1), 40-49

Yusri, R. \& Husaini, A. (2017). Pengembangan Multimedia Interaktif Menggunakan Microsoft Power Point Dalam Pembelajaran Matematika Kelas $\mathrm{X}$ MA KM Muhammadiyah Padang Panjang. Jurnal IPTEK Terapan. 11(1), 1-8 